indirect risk factor for cardiovascular diseases. This study provides no support, however, for the hypothesis that poverty in childhood itself is causally related to myocardial infarction.

1 Barker DJP, Osmond C. Infant mortality, childhood nutrition, and ischaemic heart disease in England and Wales. Lancet 1986;i:1077-81.

2 Barker DJP, Osmond C, Golding J, Kuh D, Wadsworth MEJ. Growth in utero, lood pressure in childhood and adult life, and mortality from cardiovascular disease. Br Med f 1989;298:564-7.

3 Hasle $\mathrm{H}$, Jeune B. Childhood conditions and disability pension [English Abstract]. Ugeskr Laeger 1989;151:1926-8.

4 Williams DRR, Roberts SJ, Davies TW. Deaths from ischaemic heart disease and infant mortality in England and Wales. I Epidemiol Community Health 1979;33:199-202.

5 Pocock SJ, Shaper AG, Cook DG, Phillips AN, Walker M. Social class differences in ischaemic heart disease in British men. Lancet 1987;ii:197-201.

Accepted 29 November 1989)

\section{Intravenous thrombolysis for suspected myocardial infarction: a cautionary note}

\author{
Nicholas P Curzen, Bernard Clarke, \\ Huon H Gray
}

\section{Wessex Regional}

Cardiothoracic Unit,

Southampton General

Hospital, Southampton

SO9 4XY

Nicholas P Curzen, BM, senior house officer

Bernard Clarke, MD, senior registrar

Huon H Gray, MD, consultant cardiologist

Correspondence to: $\mathrm{Dr}$ Gray.

$\operatorname{Br} \operatorname{Med} \mathcal{f} 1990 ; 300: 513$

Use of thrombolytic agents to treat acute myocardial infarction reduces mortality by $10-30 \%,,^{1+}$ and an increasing number of patients are now receiving such agents. We report two cases in which administration of streptokinase was probably inappropriate and had adverse consequences.

\section{Case reports} to hospital with a one hour history of anterior chest pain radiating through to her back. Although an electrocardiogram was normal, acute myocardial infarction was diagnosed clinically and intravenous
Case 1-A previously fit 75 year old woman presented streptokinase ( 1.5 million units over one hour) given. Eighteen hours later she developed further chest pain, which radiated to her legs, and an early diastolic murmur. A chest radiograph suggested a widened mediastinum, and she was transferred to the regional cardiothoracic unit with a diagnosis of aortic dissection. Aortography showed a type A dissection, but she died during an emergency operation. A postmortem examination did not show any appreciable disease of the coronary arteries.

Case 2-A previously fit 64 year old woman was admitted to her district hospital after the sudden onset of central chest pain several hours earlier. Electrocardiography showed inferior $\mathrm{T}$ wave inversion, and acute myocardial infarction was diagnosed. Intravenous streptokinase was given $(1.5$ million units over one hour), but three hours later she became hypotensive and collapsed. Echocardiography showed a pericardial effusion, and she was transferred to the regional cardiothoracic unit. On arrival she was hypotensive and could not be roused. Initially an aortogram was thought to be normal, and coronary arteriography was therefore undertaken; the results of this were normal. Subsequent analysis of the cineangiogram showed subtle changes consistent with type A disssection, and after resuscitation she was referred for urgent surgery, which confirmed the diagnosis. She was well four months later.

\section{Comment}

The reductions in infarct size and mortality from cardiovascular causes are greater the earlier thrombolytic agents are administered. As changes evident on electrocardiography may take time to develop some hospitals require only clinical criteria of infarction before thrombolytic agents are given. Most of the large trials of thrombolytic agents required electrocardiographic evidence of infarction before the agents were given, but two did not. ${ }^{34}$ In one of these, the AngloScandinavian study of early thrombolysis (ASSET), subset analysis showed that thrombolytic agents did not result in any significant reduction in mortality in patients with normal electrocardiograms.

Contraindications to the use of thrombolytic agents are well documented, but most trials do not report on patients whose condition was misdiagnosed and who received thrombolytic agents inappropriately. In the trials that required changes evident on electrocardiography $^{12}$ it is possible that there were no such cases or that they were unrecognised. In the Anglo-Scandinavian trial, however, eight patients were subsequently shown to have aortic dissection, of whom five died. Although dissection might conceivably have resulted from thrombolytic treatment, more probably the initial diagnosis was incorrect. As myocardial infarction may itself complicate type A aortic dissection, thrombolytic agents will inevitably be given to a few patients with dissection, even if electrocardiographic evidence of infarction is required before the drugs are administered.

The benefit offered by thrombolytic agents to the many patients with acute myocardial infarction is obvious. Our experience suggests that in the enthusiasm for using these agents some patients will be treated inappropriately and that such treatment may be life threatening. This raises the question of whether greater emphasis should be placed on the presence of electrocardiographic changes. If all general practitioners are to own an electrocardiograph, as recently recommended, 5 and are to be encouraged to start thrombolysis then guidelines on the relevance of electrocardiographic changes will need to be clearly stated.

1 Gruppo Italiano per lo Studio della Streptochinasi nell Infarto Miocardico (GISSI). Effectiveness of intravenous thrombolytic treatment in acu myocardial infarction. Lancet 1986;i:397-402.

2 Intravenous Streptokinase in Acute Myocardial Infarction Study Group. A prospective trial of intravenous streptokinase in acute myocardial infarction (ISAM): mortality, morbidity, and infarct size at 21 days. $N$ Engl $f$ Med 1986;314:1465-71

3 Wilcox RG, Olsson CG, Skene AM, van der Lippe G, Jenson G, Hampton JR. Trial of tissue plasminogen activator for mortality reduction in acute Tha myocardial infarction: Anglo-Scan

4 ISIS-2 (Second International Study of Infarct Survival) Collaborative Group. Randomised trial of intravenous streptokinase, oral aspirin, both or neither among 17,187 cases of acute myocardial infarction (ISIS-2). Lancet 1988;ii: among

5 Davies A. Electrocardiographs in general practice. $\mathrm{Br}$ Med $\mathcal{F}$ 1989;299:408-9.

(Accepted 10 November 1989) 